Journal of Zhejiang University-SCIENCE C (Computers \& Electronics)

ISSN 1869-1951 (Print); ISSN 1869-196X (Online)

www.zju.edu.cn/jzus; www.springerlink.com

E-mail: jzus@zju.edu.cn

\title{
Erratum:
}

\section{Erratum to: Dynamic task scheduling modeling in unstructured heterogeneous multiprocessor systems}

\author{
Hamid TABATABAEE $^{\dagger 1}$, Mohammad Reza AKBARZADEH-T ${ }^{2,3}$, Naser PARIZ $^{3}$ \\ ( ${ }^{I}$ Department of Computer Engineering, Quchan Branch, Islamic Azad University, Quchan, Iran) \\ $\left({ }^{2}\right.$ Center of Excellence on Soft Computing and Intelligent Information Processing, Ferdowsi University of Mashhad, Mashhad, Iran) \\ $\left({ }^{3}\right.$ Department of Electrical Engineering, Ferdowsi University of Mashhad, Mashhad, Iran) \\ 'E-mail: hamid.tabatabaee@Iauq.ac.ir
}

doi:10.1631/jzus.C13e0204

Erratum to: J Zhejiang Univ-Sci C (Comput \& Electron) 2014 15(6):423-434 doi:10.1631/jzus.C1300204

The original version of this article unfortunately contained a mistake. The affiliation of the first author was incorrect. The correct affiliation is: Department of Computer Engineering, Quchan Branch, Islamic Azad University, Quchan, Iran.

The online version of the original article can be found at http://dx.doi.org/10.1631/jzus.C1300204 (C) Zhejiang University and Springer-Verlag Berlin Heidelberg 2014 